\title{
1 Baseline and oxidative DNA damage in marine invertebrates
}

2

3 Running head: Oxidative DNA damage in marine invertebrates

4

5

6 Andrea Sahlmann ${ }^{1,}$, Raoul Wolf ${ }^{1}$, Tor Fredrik Holth ${ }^{1,2}$, Josefin Titelman ${ }^{1}$,

$7 \quad$ Ketil Hylland ${ }^{1}$

8

$9 \quad{ }^{1}$ Department of Biosciences

10 University of Oslo

11 P.O. box 1066 Blindern

$12 \quad \mathrm{~N}-0316$ Oslo

13 Norway

14

$15 \quad{ }^{2}$ current address: Fylkesmannen i Vestfold

16 P.O. box 2076

$17 \quad$ N-3103 Tønsberg

18 Norway

19

$20{ }^{*}$ Corresponding author: a.s.sahlmann@,ibv.uio.no

22 Key words: comet assay, DNA strand breaks, invertebrates, coelomocytes, hemocytes 


\section{Authors details:}

24 Andrea Sahlmann

25 Department of Biosciences

26 University of Oslo

27 P.O. box 1066 Blindern

$28 \quad$ N-0316 Oslo

29 Norway

30 phone: $+47-22854506$

31 e-mail: a.s.sahlmann@ibv.uio.no

32

33 Josefin Titelman

34 Department of Biosciences

35 University of Oslo

36 P.O. box 1066 Blindern

$37 \quad$ N-0316 Oslo

38 phone: +4722854501

39 e-mail: josefin.titelman@ibv.uio.no

40

41 Tor Fredrik Holth

42 Fylkesmannen i Vestfold

43 P.O. box 2076

$44 \quad$ N-3103 Tønsberg

45 Norway

46 phone: +4733371192

47 e-mail: fmvetfh@fylkesmannen.no
Raoul Wolf

Department of Biosciences

University of Oslo

P.O. box 1066 Blindern

N-0316 Oslo

Norway

phone: +47-22854506

raoul.wolf@ibv.uio.no

Ketil Hylland

Department of Biosciences

University of Oslo

P.O. box 1066 Blindern

N-0316 Oslo

phone: +4722857315

e-mail: ketil.hylland@ibv.uio.no 
Anthropogenic pollutants cause oxidative stress in marine organisms, directly or following generation of reactive oxygen species, potentially resulting in increased

51 accumulation of DNA strand breaks. We quantified baseline levels of DNA strand breaks in marine species from four phyla and assessed their relative sensitivity to oxidative stress, as well as capacity to recover.

DNA strand breaks were quantified using a formamidopyrimidine DNA glycosylase (Fpg)-amended comet assay on circulating cells from blue mussel (Mytilus edulis), shore crab (Carcinus maenas), sea star (Asterias rubens) and vase tunicate (Ciona intestinalis). Lymphocytes from Atlantic cod (Gadus morhua) were used as a reference. In addition to immediate analysis, cells from all species were exposed ex vivo to two concentrations of $\mathrm{H}_{2} \mathrm{O}_{2}(25$ and $250 \mu \mathrm{M})$ prior to being assayed.

Mean baseline DNA strand breaks were highest for cells from sea star (34\%) followed by crab (25\%) mussel (22\%), tunicate $(17 \%)$ and cod (14\%). Circulating cells from invertebrates were much more sensitive to oxidative stress than were cod lymphocytes. DNA strand breaks exceeded $80 \%$ for sea star, crab and mussel cells following exposure to the lowest $\mathrm{H}_{2} \mathrm{O}_{2}$ concentration. There was no recovery for cells from any species following $1 \mathrm{hr}$ in buffer. This study provides an in-depth analysis of DNA integrity for ecologically important species representing four phyla. The results indicate that circulating cells from invertebrates are much more sensitive to oxidative stress than cells from fish, measured as DNA strand breaks. Future studies should address the extent to which DNA strand breaks have consequences for body maintenance costs in marine invertebrates. 


\section{Introduction}

72 There has been an increasing focus on the genotoxic potential of anthropogenic pollutants over the past couple of decades (Bolognesi and Cirillo, 2014). Pollutants can affect DNA through several mechanisms (Bolognesi and Cirillo, 2014), including by causing oxidative stress. Intracellular production of radicals can overcome antioxidant defences, resulting in oxidative damage to other macromolecules such as lipid peroxidation, DNA strand breaks and alterations in critical cellular processes (Livingstone, 2003).

Knock-on effects of DNA damage include cell death, mutation, carcinogenesis and genotoxicity, with long-term consequences of which may include embryonal aberration (Barranger et al., 2014), reduced hatching rates, gamete development and reduced fitness (Lee et al., 2012; Linhartova et al., 2013; Matić et al., 2016). Measures of DNA damage provide an early warning signal of genotoxic exposure (Rybakovas et al., 2009). Fish and mussels have served as useful indicator species in ecotoxicological and genotoxicity studies (reviewed in Frenzilli et al., 2009; Lee and Steinert, 2003). Interspecies differences in vulnerability to toxicity have led to the inclusion of additional invertebrate species such as polychaetes and sea urchins (Lewis and Galloway, 2008; Pinsino and Matranga, 2015). There is however still limited understanding of DNA damage and repair in invertebrates. Mussels, sea stars, crabs and tunicates are present in most coastal ecosystems and representatives of those groups were selected as model

91 organisms in this study.

92 Antioxidant activity and DNA repair mechanisms such as base excision repair play a 93 major role in balancing out the continuous damage to DNA caused by radicals (Collins 94 et al., 1997). The antioxidant system includes both antioxidant enzymes such as 95 glutathione peroxidase, catalase and superoxide dismutase and antioxidants like 
96 glutathione (Birben et al., 2012). Impaired antioxidant defence and DNA repair will

97 increase base oxidation and DNA strand breaks (Azqueta et al., 2009). Persistent

98 genotoxic damage depends on the balance between repair and replacement of damaged

99 cells (El-Bibany et al., 2014). Differences in the replacement of damaged cells

100 specifically, and cell proliferation rate in general may affect species relative sensitivity

101 to accumulate DNA damage. For example, echinoderms had low levels of cell 102 proliferation compared to vertebrates (Dixon et al., 2002; Hernroth et al., 2010; Holm

103 et al., 2008).

104 DNA damage in terms of strand breaks can easily be quantified with the comet assay, 105 a method widely used in both human toxicology and ecotoxicology (Collins et al., 1997;

106 Frenzilli et al., 2009). The comet assay also allows for quantification of DNA repair 107 capacity by measuring removal of DNA strand breaks (Collins, 2004). In addition, by 108 including a base excision repair enzyme such as formamidopyrimidine DNA 109 glycosylase (Fpg), oxidised nucleotides can also be quantified (Collins and Azqueta, 110 2011). Although not inherently limited to a species or cell type, use of the comet assay

111 in ecotoxicology has to a large extent been limited to studies using fish or mussels (de 112 Lapuente et al., 2015). There is however a large potential in using the comet assay to 113 assess genotoxicity in circulating cells from species from other taxonomic groups.

114 Genotoxicity studies using the comet assay require preparations with dissociated cells, 115 either cells already in suspension or cells separated prior to performing the assay. The 116 assay has however been most widely used with blood cells or sperm from humans and 117 vertebrates (Collins and Azqueta, 2011) or hemocytes or coelomocytes from 118 invertebrates - the equivalent to human blood cells (Dhawan et al., 2009). Hemocytes 119 and coelomocytes are involved in essential functions such as nutrient and oxygen 120 transport, immunity and wound healing (Matranga et al., 2005). Cell characteristics and 
121 the abundance of different cell types vary between phyla, species and even among

122 individuals (Arizza and Parrinello, 2009; Carballal et al., 1997; Söderhäll and Smith,

123 1983). In addition, pollution and traumatic events may alter the relative cell abundance

124 (Hernroth et al., 2010; Matranga et al., 2006; Pinsino et al., 2007). Specific cells differ

125 in their sensitivity to DNA damaging agents. For example, circulating cells appear to

126 be less sensitive to DNA damaging agents than gill, digestive gland or sperm cells

127 (Frenzilli et al., 2009). Mammalian lymphocytes are particularly robust (Andreoli et al.,

128 1999; Collins et al., 1995), whereas circulating cells from invertebrates have more

129 variable sensitivity (Venier et al., 1997; Lewis and Galloway, 2008). However,

130 implications of changes in cell composition for species susceptibility to genotoxicity

131 remain poorly understood. To evaluate possible differences in the susceptibility of

132 circulating cells to DNA damage, it is crucial to have knowledge about natural baseline

133 levels in the species investigated.

134 This study aimed to determine genotoxic responses in coelomocytes and hemocytes of

135 M. edulis, A. rubens, C. maenas and C. intestinalis by quantifying 1) baseline levels of

136 DNA strand breaks, 2) species-specific responses to oxidative stress, and 3) recovery

137 of the cells following oxidative stress. 


\section{Reagents}

140 All chemicals and reagents were purchased from Sigma Aldrich (St. Louis, MO, USA),

141 Merck (Kenilworth, NJ, USA) and VWR (Radnor, PA, USA) unless stated otherwise.

142 The DNA repair enzyme Fpg $\left(20 \mathrm{ng} \mathrm{mL}^{-1}\right)$, was kindly provided by Gunnar Brunborg

143 (Norwegian Health Institute, Oslo, Norway).

\section{Animal collection}

146 Animals were collected outside their natural breeding season. Ciona intestinalis,

147 Asterias rubens, and Carcinus maenas were collected by divers in the outer Oslofjord

148 in the vicinity of Drøbak $\left(59.66^{\circ} \mathrm{N}, 10.59^{\circ} \mathrm{E}\right)$, Norway in March 2013, and maintained

149 at Drøbak Aquarium until assessment. Mytilus edulis were collected from control site

150 and kept in outdoor tanks with running seawater until use. The pollution load in outer

151 Oslofjord has been studied for several years and may be characterised as moderate

152 (Green et al., 2014). All species were maintained at their local environmental conditions

153 or acclimated to new conditions.

154 Lymphocytes from Atlantic cod (Gadus morhua) were included as reference based on 155 previous experience in our group on oxidative stress responses and DNA damage 156 (Fredriksen, 2013). Cod were collected from outer Oslofjord and transported to Drøbak 157 Biological Station, University of Oslo where they were held in outdoor tanks supplied 158 with running seawater.

\section{9}

\section{Cell sampling}

161 Syringes (Sarstedt, $1 \mathrm{~mL}$ ) were rinsed and preloaded with $0.2 \mathrm{~mL}$ ice-cold PBS (14.5 $\mathrm{mM} \mathrm{NaCl}, 0.6 \mathrm{mM} \mathrm{Na}_{2} \mathrm{HPO}_{4}, 0.4 \mathrm{mM} \mathrm{KH}_{2} \mathrm{HPO}_{4}, 10 \mathrm{mM}$ EDTA, $\mathrm{pH}=7.4$ ) before use. 
$163 \mathrm{pH}$ and osmolality were adjusted to the respective tissue characteristics (G. morhua:

$164 \mathrm{pH}=7.4$ and $340 \mathrm{mOsm}$; invertebrates: $\mathrm{pH}=7.4$ and $700 \mathrm{mOsm}$ ).

165 Gadus morhua $(n=8)$ were sacrificed and $1 \mathrm{~mL}$ blood was withdrawn from the caudal

166 vein and white blood cells were isolated by discontinous Percoll gradient centrifugation

167 (with densities: 1.05, 1.06, and $1.07 \mathrm{~g} \mathrm{~mL}^{-1}$ ) spun at $400 \mathrm{G}$ for $40 \mathrm{~min}$ and cells 168 collected from the $1.05: 1.06 \mathrm{~g} \mathrm{~mL}^{-1}$ interface.

$1690.8 \mathrm{~mL}$ circulating fluid was sampled of each invertebrate species (with $n=8$ per

170 species). C. maenas was bled from an unsclerotized membrane of the pereiopods. $M$.

171 edulis hemolymph was withdrawn from the aductor muscle. Coelomic fluid of $A$.

172 rubens was sampled from the coelomic cavity and $C$. intestinalis coelomic fluid was

173 extracted from visceral cavity by inserting a syringe from posterior side.

174 Cell density was determined using a Bürker-Türk hemocytometer and cell viability was 175 assessed using the trypan blue exclusion test. Cell viability was $>90 \%$ for all 176 preparations.

\section{Comet assay}

179 Single strand DNA breaks were measured using the alkaline comet assay as described 180 by Singh et al. (1988) with modifications by Tice et al. (2000). Briefly, cells were 181 diluted in PBS and embedded in $0.75 \mathrm{wt} \%$ low melting point agarose in PBS before 25 $182 \mu \mathrm{L}$ of this mixture was transferred onto a hydrophilic GelBond film (Lonza, Basel,

183 Switzerland) (Gutzkow et al., 2013) with a final concentration of approximately 1.250 184 cells gel $^{-1}$. One gel per individual per species was applied to one film per treatment. 185 Films placed in boxes with 0,25 and $250 \mu \mathrm{M} \mathrm{H}_{2} \mathrm{O}_{2}$ in PBS and embedded cells were 186 exposed for $15 \mathrm{~min}$ at $15{ }^{\circ} \mathrm{C}$. After being rinsed in $\mathrm{dH}_{2} \mathrm{O}$, one films was placed in PBS 187 without EDTA for $1 \mathrm{~h}$ at $15{ }^{\circ} \mathrm{C}$ to allow for DNA repair. After exposure, films were 

mM EDTA, $10 \mathrm{mM}$ Tris, 1 vol\% Triton $\mathrm{X}-100$, and $\mathrm{pH}=10$ ) in the dark. DNA damage

190 levels are stable for up to three weeks when immersed in ice-cold lysis buffer (Collins,

191 2014; Hylland et al., 2016). Films were rinsed in $\mathrm{dH}_{2} \mathrm{O}$, placed in cold Collins' buffer 192 (40 mM HEPES, $100 \mathrm{mM} \mathrm{KCl}, 500 \mu \mathrm{M}$ EDTA, $\mathrm{pH}=7.6$ ) for $60 \mathrm{~min}$, and incubated in 193 fresh Collins' buffer containing BSA (40 $\left.\mathrm{mg} \mathrm{mL}^{-1}\right)$ and incubation with Fpg was for 1 $194 \mathrm{~h}$ at $15^{\circ} \mathrm{C}$. DNA unwinding was performed in electrophoresis buffer $(300 \mathrm{mM} \mathrm{NaOH}$, $1951 \mathrm{mM}$ EDTA and $6 \mathrm{vol} \%$ concentrated $\mathrm{HCl}, \mathrm{pH}>13$ ) for $20 \mathrm{~min}$ before electrophoresis 196 was run at $15 \mathrm{~V}$ for $25 \mathrm{~min}$. The films were rinsed in neutralization buffer $(400 \mathrm{mM}$ 197 Tris and $\mathrm{pH}=7.5$ ) for $15 \mathrm{~min}$ at room temperature. After films were rinsed in $\mathrm{dH}_{2} \mathrm{O}$, 198 they were fixed in $96 \%$ ethanol for $1.5 \mathrm{~h}$ and air dried overnight in darkness. DNA was 199 stained with $1 \times$ SYBR Gold (Life Technologies, Carlsbad, CA, USA) in TE buffer (10 $200 \mathrm{mM}$ Tris, $1 \mathrm{mM}$ EDTA, and $\mathrm{pH}=8$ ) for $20 \mathrm{~min}$ at room temperature in darkness prior 201 to scoring using a Leica DMR fluorescence microscope with an objective with 40× 202 magnification. Fluorescence was read at 520/610 nm excitation/emission. 50 cells gel $^{-1}$ 203 were scored and DNA damage, in terms of DNA strand breaks, was quantified using 204 Comet Assay IV software (version 4.3; Perceptive Instruments; Bury St Edmunds, 205 UK).

\section{Statistics}

208 DNA damage data was analyzed and visualized using open-source statistical software 209 R (version 3.3.2; R Core Team 2016) and its add-on packages nlme (version 3.1-128;

210 Pinheiro et al., 2017) and multcomp (version 1.4-6; Hothorn et al., 2008).

211 Baseline values were analyzed using a linear mixed effects (LME) model with species 212 as fixed effect and individuals as random factor. Intra-species differences in DNA 
213 damage after peroxide exposures were analyzed in paired $t$-tests following non214 significant Shapiro-Wilk and $F$-tests. Inter-species differences were analyzed in an 215 LME model with species and peroxide treatments as fixed effects, and individuals as 216 random factor. Recovery abilities were analyzed in an LME model with species as fixed 217 effect, and individuals as random factor. Differences in species responses to peroxide 218 exposure and subsequent recovery were analyzed in an LME model with species, 219 peroxide treatments, and recovery as fixed effects, and individuals as random factors.

220 For all LME models DNA damage was the response variable, and inter-species 221 differences were analyzed after significant Wald $F$-tests with marginal (type III) sum 222 of squares for the respective fixed effects and subsequent multiple comparisons of 223 means with Tukey contrasts and Holm's $P$-value adjustment for multiple comparisons 224 (Bretz et al., 2011). A level of significance of $P=0.05$ was set for the rejection of the 225 null-hypothesis. 


\section{Results}

227 Baseline DNA damage for all species increased as follows: G. morhua $(14 \%)<C$. intestinalis $(17 \%)<$ M. edulis $(22 \%)<$ C. maenas $(25 \%)<$ A. rubens $(34 \%)$ (mean

229 values; Fig. 1). There were no statistical differences in baseline DNA damage between 230 cells from M. edulis, C. maenas, C. intestinalis and G. morhua. Cells from A.rubens 231 had higher baseline levels than cells from G. morhua and C. intestinalis $(P<0.01$ and $232 P<0.05$, respectively).

233 Both peroxide treatments resulted in increased DNA damage compared to baseline 234 values (invertebrates $P<0.05$, G. morhua $P<0.001$; Fig. 2). DNA damage increased 235 3-4 fold compared to baseline values in the four invertebrate species. Total DNA 236 damage exceeded $80 \%$ in M. edulis, A. rubens and C. maenas following exposure to 25 $237 \mu \mathrm{M} \mathrm{H}_{2} \mathrm{O}_{2}$. DNA damage increased 2-3 fold following peroxide exposure compared to 238 baseline values for cells from C. intestinalis and G. morhua.

239 In M. edulis and G. morhua, DNA damage increased following exposure $250 \mu \mathrm{M} \mathrm{H}_{2} \mathrm{O}_{2}$ 240 compared to $25 \mu \mathrm{M} \mathrm{H}_{2} \mathrm{O}_{2}(P<0.05$ and 0.01 , respectively). There was no significant 241 change in DNA in cells from M. edulis, A. rubens, C. intestinalis following exposure 242 to $250 \mu \mathrm{M} \mathrm{H}_{2} \mathrm{O}_{2}$ and subsequent recovery, but increased in C. maenas and G. morhua $243(P<0.05$ and $P<0.001$, respectively; Fig. 3). Significantly increased levels of DNA 244 strand breaks following incubation with Fpg were observed in cells from A. rubens and 245 C. intestinalis $(P<0.05)$, C. maenas and G. morhua $(P<0.001)$ (Fig. 4). In A. rubens 246 and $C$. maenas oxidised lesions accounted for $3-5 \%$ additional strand breaks. $C$. 247 intestinalis and G. morhua had 21\% and 29\% additional strand breaks following Fpg248 amendment.

249 Peroxide exposure caused higher DNA damage in M. edulis and A. rubens compared to 250 C. intestinalis and G. morhua $(P<0.001$; Fig. 2). C. maenas and C. intestinalis did not 
251 differ in their exposure responses. Lymphocytes from G. morhua had lower DNA 252 damage than the invertebrate cells $(P<0.001$; Fig. 2). Following recovery, DNA 253 damage increases in cells from C.maenas and G. morhua $(P<0.05$ and 0.001 , 254 respectively; Fig. 3). 


\section{Discussion}

256 We quantified species-specific differences in baseline DNA damage, in susceptibility 257 to oxidative stress and DNA repair capacity of four common and widely distributed 258 invertebrates from different phyla. The circulating cells from the invertebrates were 259 more susceptible to DNA damage caused by oxidative stress than were cod 260 lymphocytes. For cod, which was included as a reference species, both baseline DNA 261 strand breaks and the responses following oxidative stress agreed with published data 262 (Fredriksen, 2013), indicating consistent results from the assay.

263 To our knowledge this is the first time that DNA damage was determined quantitatively 264 in an ascidian using the comet assay (but see Ballarin et al., 2008; Liu et al., 2006). A 265 summary of published studies suggests that chordates, such as tunicate and fish, 266 generally exhibit lower baseline DNA strand breaks than the species from the other 267 phyla (Table 1, references therein). Such differences could be due to differences 268 between species in cell or protein turnover or different constitutive levels of DNA repair 269 (Collins et al., 2001; Siu et al., 2004; Siu et al., 2003).

270 Within taxa different levels of baseline DNA damage may reflect differences in animal 271 state or methods as standardised comet assay protocols are lacking for most 272 invertebrates (Dixon et al., 2002; Martins and Costa, 2015). Levels of DNA damage in 273 coelomic epithelial and pyloric caeca cells of $A$. rubens (Everaarts, 1995; Hernroth et 274 al., 2010) are similar to the levels found in this study (Table 1). Canty et al. (2009), 275 however, observed lower levels of DNA damage in sea star coelomocytes.

276 DNA damage increased in circulating cells from all invertebrate species and treatments, 277 with $C$. intestinalis cells apparently being the most robust. The damage observed for $M$. 278 edulis, A. rubens and C. maenas cells exposed to the lowest $\mathrm{H}_{2} \mathrm{O}_{2}$ concentration was 279 close to the upper limit of damage detection, as cells with totally fragmented DNA may 
be overlooked or disregarded (Kumaravel et al., 2009, Lorenzo et al., 2013). Hence, the

281 observed additional increases in DNA damage following exposure to a ten times higher concentration of $\mathrm{H}_{2} \mathrm{O}_{2}$ or Fpg-amendment were small. The results agree with previous observations of little additional increase of DNA damage in mussel gill cells exposed

284 to higher concentrations than $100 \mu \mathrm{M} \mathrm{H}_{2} \mathrm{O}_{2}$ (Wilson et al., 1998). Although small, the increase in oxidised DNA damage (detected using Fpg-treatment) was significant for all invertebrate species except mussel, which was probably due to the high initial DNA damage in that species. Fpg-amendment thus appears to be a useful addition to the comet assay for invertebrates, as well as for vertebrates (Collins, 2014). Increased

289 levels of oxidised lesions have previously been detected using a Fpg-amended comet assay for bivalve hemocytes and gill cells (Gielazyn et al., 2003; Michel and VincentHubert, 2012). Similar concentrations of $\mathrm{H}_{2} \mathrm{O}_{2}$ as used in our study resulted in increased DNA damage in mussel digestive gland cells and hemocytes (Lee and Steinert, 2003;

293 Mitchelmore et al., 1998).

294 Varying levels of relative sensitivity have been reported in invertebrates exposed to 295 different contaminants (Table 2, references therein). Many species had higher 296 sensitivity than blue mussel (Table 2). Looking at tissue sensitivity, gill cells were more 297 sensitive than digestive gland and hemolymph cells in bivalves (Rigonato et al., 2005; 298 Pereira et al., 2011). Based on the latter studies and studies in Table 2, it appears, that 299 sensitivity is tissue-specific at a species level and can differ between species within a 300 taxonomic group. Immediate exposure responses were similar in the three sea urchins 301 species studied by El-Bibany et al. (2014; Table 2). However, the species differed in 302 their ability to repair strand breaks indicated by slower recovery in one of the species. 303 These differences suggest that repair capacity could have an important role in species 304 sensitivity to genotoxic compounds (see below). The differences in sensitivity between 
mussel hemocytes and fish lymphocytes in the present study are consistent with the results in (Mamaca et al., 2005), who observed a higher sensitivity of mussel hemocytes

307 compared to fish erythrocytes. Contrasting our findings of equal sensitivity in mussel 308 and sea star cells exposed to peroxide, Canty et al. (2009) observed that echinoderm 309 coelomocytes were more sensitive to MMS exposure than bivalve hemocytes. Both 310 MMS and peroxide are direct acting mutagens but through different mechanisms 311 (MMS: alkylating; $\mathrm{H}_{2} \mathrm{O}_{2}$ : oxidising), which may explain the contrasting findings.

312 Sea urchin coelomocytes appear to be relatively robust to several DNA-damaging 313 agents (Reinardy et al., 2015; El-Bibany et al., 2014) and are less sensitive to $\mathrm{H}_{2} \mathrm{O}_{2}$ and 314 UV exposure than cells from the sea hare (Aplysia dactylomela), a mollusc, and the 315 carribean spiny lobster (Panulirus argus), a crustacean (Loram et al., 2012). Our results 316 indicated similar sensitivity of circulating cells from $C$. maenas, M. edulis and A. 317 rubens at low peroxide concentration. Further studies with lower levels of oxidative 318 stress are required to find the thresholds of impact for those three species.

319 It is not obvious why cod lymphocytes were less sensitive to oxidative stress than 320 circulating cells from the invertebrate species. One possible explanation is that 321 vertebrate lymphocytes have inherently low levels of DNA damage and are robust 322 against developing DNA strand breaks (Collins et al., 1995; Collins and Azqueta, 2011; 323 Andreoli et al., 1999). Secondly, the partial pressure of oxygen is higher in fish blood 324 than in circulating fluid of the invertebrate species (Abele and Puntarulo, 2004) 325 necessitating a more efficient cellular defence against oxidative stress. Finally, fish 326 lymphocytes have higher general metabolism than circulating cells in invertebrates 327 (Ekau et al., 2010) Higher metabolism will often lead to higher intracellular generation 328 of radicals. Fish cells will therefore require more efficient cellular mechanisms against 329 oxidative stress (see below). 
330 Since exposure of the cells were done in vitro, factors associated with uptake, 331 bioaccumulation or biotransformation are irrelevant, so the observed differences in 332 sensitivity will relate directly to cellular defence and repair capability (Lewis and 333 Galloway, 2008). Any differences in antioxidant defence contribute to the observed 334 differences in DNA damage levels and species-specific sensitivity.

335 Antioxidant enzyme activities differ for M. edulis, C. maenas and A. rubens, as mussel 336 and sea star had much higher enzymes activities in their digestive gland, respiratory 337 tissue and muscle tissues compared to crab (Gamble et al., 1995). Phylogenetic 338 differences in antioxidant enzymes activities exist and they are generally lower in 339 invertebrates compared to vertebrates (Livingstone et al., 1992). Glutathione 340 peroxidase (GPx), a central enzyme in $\mathrm{H}_{2} \mathrm{O}_{2}$ detoxification in mammalian cells 341 (Gamble et al., 1995) has generally 1-2 fold lower activities in invertebrates than 342 vertebrates (Livingstone et al., 1992). Enzyme isoforms of GPx exist in chordates that 343 are not found in molluscs, arthropods and echinoderms that could result in phylogenetic 344 differences in the biochemical properties and enzyme efficiency (Bae et al., 2009; 345 Margis et al., 2008). Two other relevant enzymes, superoxide dismutase and catalase, 346 are similarly or more active in invertebrates compared to vertebrates (Livingstone, 347 2001).

348 While cod blood was separated for white blood cells, invertebrate samples constituted 349 whole hemolymph and coelomic fluid. Their circulating fluids comprise a mixture of 350 morphologically distinct cells; ranging from two cell types in mussels to up to eight 351 different cell types in the tunicate (Arizza and Parrinello, 2009; Carballal et al., 1997; 352 Johansson et al., 2000; Pinsino et al., 2007). In all species, however, one cell type is 353 generally numerically dominant. The subpopulations of cells have distinct functions 354 (Hibino et al., 2006; Matranga et al., 2006) and differ probably also in their ability to 
355 sense and repair DNA damage (Loram et al., 2012). Cell-specific sensitivities to DNA

356 damaging agents are present in mussel hemolymph (Venier et al., 1997) and polychaete

357 coelomic fluid (Lewis and Galloway, 2008). Also, cell composition or the number of

358 individual cell types may change as a result from pollution or traumatic events

359 (Hernroth et al., 2010; Matranga et al., 2006; Pinsino et al., 2007). Peroxide exposure

360 increased the numbers of sea urchin amoebocytes (El-Bibany et al., 2014). Further

361 studies may shed light on the susceptibility of individual circulating cell types or

362 implications of cell composition and abundance to DNA damage or repair capacity.

363 Following $1 \mathrm{hr}$ recovery, DNA damage increased in all species consistent with

364 increased damage in mussel gill cells exposed to peroxide (Dixon et al., 2002). Likely,

365 this is due to accumulation of cellular damage subsequently resulting in DNA strand

366 breaks (Marnett, 2002) as well as primary DNA repair steps (Rastogi et al., 2010;

367 Wilson and Bohr, 2007). The latter have been attributed to increased DNA strand

368 breaks in mussel cells, sea urchin coelomocytes and grass shrimp embryos (Dixon et

369 al., 2002; El-Bibany et al., 2014; Hook et al., 2004).

370 DNA repair capability is a particularly important determinant of susceptibility 371 (Depledge, 1998). Small differences in the efficiency of DNA repair can result in up to 372 10-fold differences in susceptibility to genotoxicants (Hemminki et al., 1991). The 373 significant increase of strand breaks in cod lymphocytes could reflect more efficient 374 DNA repair compared to invertebrates. Indeed, fish cells repaired strand breaks 375 efficiently within one to four hours (Nacci et al., 1996). Rainbow trout larvae had high 376 rate of excision repair (Mitchell et al., 2009). Substantial or complete recovery from 377 DNA damage occurred only within a few hours or days in sea urchins and bivalves 378 (Akcha et al., 2000; El-Bibany et al., 2014; Pruski and Dixon, 2003). Sensitivity and 379 repair capacity are also related to developmental stages. Sea urchin larvae were more 
380 sensitive and had lower repair capacity than adult coelomocytes exposed to MMS, $\mathrm{H}_{2} \mathrm{O}_{2}$ 381 and UVC (Reinardy et al., 2015).

382 Additionally, species differ in their rate of replacing damaged cells. Echinoderms have 383 low levels of cell proliferation than vertebrates (Dixon et al., 2002; Hernroth et al., 384 2010; Holm et al., 2008). Different cell proliferation rates may affect species sensitivity 385 to DNA damage due to damage accumulation. 
387 Baseline DNA damage of circulating cells of four invertebrate species from different 388 phyla ranged from $14 \%$ to $34 \%$ strand breaks. Ex vivo $25 \mu \mathrm{M}$ peroxide exposure for 15 389 mins caused more than $80 \%$ strand breaks in circulating cells from mussel, crab and 390 sea star, and $61 \%$ strand breaks in tunicate hemocytes, whereas the treatment gave rise 391 to $29 \%$ strand breaks in cod lymphocytes. In conclusion, the invertebrate circulating 392 cells were much more sensitive to oxidative stress than were cells from fish. Recovery 393 capacity of species should be addressed more in future studies as it will lead to a better 394 understanding of the overall susceptibility of marine invertebrates to genotoxic stress. 


\section{Acknowledgements}

396 We thank Drøbak Akvarium for holding experimental animals prior to sampling, Hans 397 Erik Karlsen, UiO, for providing support and facilities at the Drøbak Biological Station, 398 Gunnar Brunborg, FHI, for a generous gift of Fpg and Christopher Hinchcliffe and Tage 399 Bratrud for assistance during sampling. 


\section{References}

401 Abele, D., and S. Puntarulo. 2004. Formation of reactive species and induction of 402 antioxidant defence systems in polar and temperate marine invertebrates and fish. Comp Biochem Physiol A Mol Integr Physiol 138 (4):405-415.

404

405

406

407

408

409

410

411

412

413

414

415

416

417

Akcha, F., T. Burgeot, H. Budzinski, A. Pfohl-Leszkowicz, and J. F. Narbonne. 2000. Induction and elimination of bulky benzo[a]pyrene-related DNA adducts and 8 oxodGuo in mussels Mytilus galloprovincialis exposed in vivo to $\mathrm{B}[\mathrm{a}] \mathrm{P}$ contaminated feed. Mar Ecol Prog Ser 205:195-206.

AlAmri, O. D., A. B. Cundy, Y. Di, A. N. Jha, and J. M. Rotchell. 2012. Ionizing radiation-induced DNA damage response identified in marine mussels, Mytilus sp. Environ Pollut 168:107-112.

Almeida, C., C. Pereira, T. Gomes, M. J. Bebianno, and A. Cravo. 2011. DNA damage as a biomarker of genotoxic contamination in Mytilus galloprovincialis from the south coast of Portugal. J Environ Monit 13 (9):2559-2567.

Andreoli, C., P. Leopardi, S. Rossi, and R. Crebelli. 1999. Processing of DNA damage induced by hydrogen peroxide and methyl methanesulfonate in human lymphocytes: analysis by alkaline single cell gel electrophoresis and cytogenetic methods. Mutagenesis 14 (5):497-504.

Arizza, V., and N. Parrinello. 2009. Inflammatory hemocytes in Ciona intestinalis innate immune response. Invertebr Survival J 6:S58-S66.

Azqueta, A., S. Shaposhnikov, and A. R. Collins. 2009. DNA oxidation: Investigating its key role in environmental mutagenesis with the comet assay. Mutat Res Genet Toxicol Environ Mutagen 674 (1-2):101-108.

Bae, Y.-A., G.-B. Cai, S.-H. Kim, Y.-G. Zo, and Y. Kong. 2009. Modular evolution of glutathione peroxidase genes in association with different biochemical 
properties of their encoded proteins in invertebrate animals. BMC Evol Biol 9 (1):72.

Ballarin, L., A. Menin, L. Tallandini, V. Matozzo, P. Burighel, G. Basso, E. Fortunato, and F. Cima. 2008. Haemocytes and blastogenetic cycle in the colonial ascidian

Barranger, A., F. Akcha, J. Rouxel, R. Brizard, E. Maurouard, M. Pallud, D. Menard, genetic damage in the Japanese oyster induced by an environmentally-relevant exposure to diuron: Evidence of vertical transmission of DNA damage. Aquat Toxicol 146:93-104.

Birben, E., U. M. Sahiner, C. Sackesen, S. Erzurum, and O. Kalayci. 2012. Oxidative stress and antioxidant defense. World Allergy Organ J 5 (1):9-19.

Bolognesi, C., and S. Cirillo. 2014. Genotoxicity biomarkers in aquatic bioindicators. Curr Zool 60 (2):273-284.

Bretz, F., T. Hothorn, and P. H. Westfall. 2011. Multiple comparisons using R: CRC Press Boca Raton.

Canty, M. N., T. H. Hutchinson, R. J. Brown, M. B. Jones, and A. N. Jha. 2009. Linking genotoxic responses with cytotoxic and behavioural or physiological consequences: Differential sensitivity of echinoderms (Asterias rubens) and marine molluscs (Mytilus edulis). Aquat Toxicol 94 (1):68-76.

Carballal, M. J., M. C. López, C. Azevedo, and A. Villalba. 1997. Hemolymph cell types of the mussel Mytilus galloprovincialis. Dis Aquat Organ 29 (2):127-135.

Cheung, V. V., M. H. Depledge, and A. N. Jha. 2006. An evaluation of the relative sensitivity of two marine bivalve mollusc species using the comet assay. Mar Environ Res 62, Supplement 1:S301-S305. 
Collins, A. 2004. The comet assay for DNA damage and repair. Mol. Biotechnol. 26 (3):249-261.

Collins, A. R. 2014. Measuring oxidative damage to DNA and its repair with the comet assay. Biochim Biophys Acta (BBA) - General subjects 1840 (2):794-800.

Collins, A. R., M. Ai-guo, and S. J. Duthie. 1995. The kinetics of repair of oxidative DNA damage (strand breaks and oxidised pyrimidines) in human cells. Mutat Res 336 (1):69-77.

Collins, A. R., and A. Azqueta. 2011. DNA repair as a biomarker in human biomonitoring studies; further applications of the comet assay. Mutat Res Fund Mol Mech Mut In Press, Corrected Proof.

Collins, A. R., V. L. Dobson, M. Dušinská, G. Kennedy, and R. Štětina. 1997. The comet assay: what can it really tell us? Mutat Res Fund Mol Mech Mut 375 (2):183-193.

Collins, A. R., M. Dušinská, E. Horváthová, E. Munro, M. Savio, and R. Štětina. 2001. Inter-individual differences in repair of DNA base oxidation, measured in vitro with the comet assay. Mutagenesis 16 (4):297-301.

Dallas, L. J., V. V. Cheung, A. S. Fisher, and A. N. Jha. 2013. Relative sensitivity of two marine bivalves for detection of genotoxic and cytotoxic effects: a field assessment in the Tamar Estuary, South West England. Environ Monit Assess 185 (4):3397-3412.

de Lapuente, J., J. Lourenço, S. A. Mendo, M. Borràs, M. G. Martins, P. M. Costa, and M. Pacheco. 2015. The comet assay and its applications in the field of ecotoxicology: a mature tool that continues to expand its perspectives. Front Genet 6 . 
474 Depledge, M. H. 1998. The ecotoxicological significance of genotoxicity in marine invertebrates. Mutat Res Fund Mol Mech Mut 399 (1):109-122.

476

477

Dhawan, A., M. Bajpayee, and D. Parmar. 2009. Comet assay: a reliable tool for the assessment of DNA damage in different models. Cell Biol Toxicol 25 (1):5-32.

Dixon, D. R., A. M. Pruski, L. R. J. Dixon, and A. N. Jha. 2002. Marine invertebrate eco-genotoxicology: a methodological overview. Mutagenesis 17 (6):495-507.

Ekau, W., H. Auel, H. O. Pörtner, and D. Gilbert. 2010. Impacts of hypoxia on the structure and processes in pelagic communities (zooplankton, macroinvertebrates and fish). Biogeosciences 7 (5):1669-1699.

El-Bibany, A. H., A. G. Bodnar, and H. C. Reinardy. 2014. Comparative DNA damage and repair in echinoderm coelomocytes exposed to genotoxicants. PLOS ONE 9 (9):e107815.

Everaarts, J. M. 1995. DNA integrity as a biomarker of marine pollution: Strand breaks in seastar (Asterias rubens) and dab (Limanda limanda). Mar Pollut Bull 31 (412):431-438.

Everaarts, J. M., and A. Sarkar. 1996. DNA damage as a biomarker of marine pollution: strand breaks in seastars (Asterias Rubens) from the North Sea. Water Sci Technol 34 (7-8):157-162.

Fredriksen, L. 2013. Effects of environmental contaminants on Atlantic cod (Gadus morhua) from the inner Oslofjord. Master thesis. University of Oslo. 88 p. http://urn.nb.no/URN:NBN:no-37348

Frenzilli, G., M. Nigro, and B. P. Lyons. 2009. The comet assay for the evaluation of genotoxic impact in aquatic environments. Mutat Res Rev Mutat Res 681 (1):8092. 
Gamble, S. C., P. S. Goldfarb, C. Porte, and D. R. Livingstone. 1995. Glutathione peroxidase and other antioxidant enzyme function in marine invertebrates (Mytilus edulis, Pecten maximus, Carcinus maenas and Asterias rubens). Mar Environ Res 39 (1-4):191-195.

Gielazyn, M. L., A. H. Ringwood, W. W. Piegorsch, and S. E. Stancyk. 2003. Detection of oxidative DNA damage in isolated marine bivalve hemocytes using the comet assay and formamidopyrimidine glycosylase (Fpg). Mutat Res Genet Toxicol Environ Mutagen 542 (1-2):15-22.

Gomes, T., O. Araújo, R. Pereira, A. C. Almeida, A. Cravo, and M. J. Bebianno. 2013. Genotoxicity of copper oxide and silver nanoparticles in the mussel Mytilus galloprovincialis. Mar Environ Res 84 (0):51-59.

Green, N. W., M. Schøyen, S. Øxnevad, A. Ruus, I. Allan, D. Hjerman, T. Høgåsen, B. A. Beylich, J. Håvardstun, Å. K. Gudmundson Rogne, and L. Tveiten. 2014. Contaminants in coastal waters of Norway 2013. NIVA report, 6728-2014, 172 p.

Gutzkow, K. B., T. M. Langleite, S. Meier, A. Graupner, A. R. Collins, and G. Brunborg. 2013. High-throughput comet assay using 96 minigels. Mutagenesis.

Halldórsson, H. P., G. Ericson, and J. Svavarsson. 2004. DNA strand breakage in mussels (Mytilus edulis L.) deployed in intertidal and subtidal zone in Reykjavík harbour. Mar Environ Res 58 (2-5):763-767.

Hartl, M. G. J., M. Kilemade, B. M. Coughlan, J. O'Halloran, F. N. A. M Van Pelt, D. Sheehan, C. Mothersill, and N. M. O'Brien. 2006. A two-species biomarker model for the assessment of sediment toxicity in the marine and estuarine environment using the comet assay. J Environ Sci Health A Tox Hazard Subst Environ Eng 41 (5):939-953. 
Hemminki, K., Interindividual variation in the level of DNA and protein adducts in humans, in: P. Grandjean (Ed.), Ecogenetics, Chapman \& Hall, London, pp. $217-234$

Hernroth, B., F. Farahani, G. Brunborg, S. Dupont, A. Dejmek, and H. Nilsson Sköld. 2010. Possibility of mixed progenitor cells in sea star arm regeneration. $J$ Exp Zool B Mol Dev Evol 314B (6):457-468.

Hibino, T., M. Loza-Coll, C. Messier, A. J. Majeske, A. H. Cohen, D. P. Terwilliger, K. M. Buckley, V. Brockton, S. V. Nair, K. Berney, S. D. Fugmann, M. K. Anderson, Z. Pancer, R. A. Cameron, L. C. Smith, and J. P. Rast. 2006. The immune gene repertoire encoded in the purple sea urchin genome. Dev Biol 300 (1):349-365.

Holm, K., S. Dupont, H. Sköld, A. Stenius, M. Thorndyke, and B. Hernroth. 2008. Induced cell proliferation in putative haematopoietic tissues of the sea star, Asterias rubens (L.). J. Exp. Biol. 211 (16):2551-2558.

Hook, S. E., and R. F. Lee. 2004. Genotoxicant induced DNA damage and repair in early and late developmental stages of the grass shrimp Paleomonetes pugio embryo as measured by the comet assay. Aquat Toxicol 66 (1):1-14.

Hothorn, T., F. Bretz, and P. Westfall. 2008. Simultaneous inference in general parametric models. Biom J 50 (3):346-363.

Hylland, K., B. B. Skei, G. Brunborg, T. Lang, M. J. Gubbins, J. le Goff, and T. Burgeot. 2016. DNA damage in dab (Limanda limanda) and haddock (Melanogrammus aeglefinus) from European seas. Mar Environ Res 124:54-60.

Jha, A. N., V. V. Cheung, M. E. Foulkes, S. J. Hill, and M. H. Depledge. 2000. Detection of genotoxins in the marine environment: adoption and evaluation of 
an integrated approach using the embryo-larval stages of the marine mussel, Mytilus edulis. Mutat Res Genet Toxicol Environ Mutagen 464 (2):213-228.

Johansson, M. W., P. Keyser, K. Sritunyalucksana, and K. Söderhäll. 2000. Crustacean haemocytes and haematopoiesis. Aquaculture 191 (1-3):45-52.

Klobučar, G. I. V., A. Stambuk, K. Hylland, and M. Pavlica. 2008. Detection of DNA damage in haemocytes of Mytilus galloprovincialis in the coastal ecosystems of Kastela and Trogir bays, Croatia. Sci Total Environ 405 (1-3):330-337. comet assay. Aquat Toxicol 150 (0):1-8.

Kumaravel, T. S., B. Vilhar, S. P. Faux, and A. N. Jha. 2009. Comet assay measurements: a perspective. Cell Biol Toxicol 25 (1):53-64

Large A.T., J.P. Shaw, L.D. Peters , A.D. McIntosh, L. Webster, A. Mally, J.K. Chapman. 2002. Different levels of mussel (Mytilus edulis) DNA strand breaks following chronic field and acute laboratory exposure to polycyclic aromatic hyrdocarbons. Mar Environ Res 54 (3-5): 493-497

Lee, H. J., G. B. Kim, and R. F. Lee. 2012. Genotoxicity and development effects of brominated flame retardant PBDEs and UV-exposed PBDEs on grass shrimp (Palaemonetes pugio) embryo. Mar Pollut Bull 64 (12):2892-2895.

Lee, R. F., and S. Steinert. 2003. Use of the single cell gel electrophoresis/comet assay for detecting DNA damage in aquatic (marine and freshwater) animals. Mutat Res Rev Mutat Res 544 (1):43-64. 
Lewis, C., and T. Galloway. 2008. Genotoxic damage in polychaetes: a study of species and cell-type sensitivities. Mutat Res Genet Toxicol Environ Mutagen 654 (1):69-75.

Linhartova, P., I. Gazo, A. Shaliutina, and M. Hulak. 2013. The in vitro effect of duroquinone on functional competence, genomic integrity, and oxidative stress indices of sterlet (Acipenser ruthenus) spermatozoa. Toxicol In Vitro 27 (6):1612-1619.

Liu, L., C. Wu, T. Chen, X. Zhang, F. Li, W. Luo, and J. Xiang. 2006. Effects of infection of EGFP-expressing Escherichia coli on haemocytes in Ciona intestinalis. J Exp Mar Bio Ecol 332 (2):121-134.

Livingstone, D. R. 2001. Contaminant-stimulated reactive oxygen species production and oxidative damage in aquatic organisms. Mar Pollut Bull 42 (8):656-666.

Livingstone, D. R. 2003. Oxidative stress in aquatic organisms in relation to pollution and aquaculture. Rev Med Vet (Toulouse) 6 (154):427-430.

Livingstone, D. R., F. Lips, P. G. Martinez, and R. K. Pipe. 1992. Antioxidant enzymes in the digestive gland of the common mussel Mytilus edulis. Mar. Biol. 112 (2):265-276.

Loram, J., R. Raudonis, J. Chapman, M. Lortie, and A. Bodnar. 2012. Sea urchin coelomocytes are resistant to a variety of DNA damaging agents. Aquat Toxicol $124-125: 133-138$.

Lorenzo, Y., S. Costa, A. R. Collins, and A. Azqueta. 2013. The comet assay, DNA damage, DNA repair and cytotoxicity: hedghoghs are not always dead. Mutagenesis (28):427-432

Mamaca, E., R. K. Bechmann, S. Torgrimsen, E. Aas, A. Bjørnstad, T. Baussant, and S. L. Floch. 2005. The neutral red lysosomal retention assay and Comet assay 
on haemolymph cells from mussels (Mytilus edulis) and fish (Symphodus melops) exposed to styrene. Aquat Toxicol 75 (3):191-201.

Margis, R., C. Dunand, F. K. Teixeira, and M. Margis-Pinheiro. 2008. Glutathione peroxidase family - an evolutionary overview. FEBS J 275 (15):3959-3970.

Marnett, L. J. 2002. Oxy radicals, lipid peroxidation and DNA damage. Toxicology

600 181-182:219-222.

601 Martins, M., and P. M. Costa. 2015. The comet assay in environmental risk assessment 602 of marine pollutants: applications, assets and handicaps of surveying genotoxicity in non-model organisms. Mutagenesis 30 (1):89-106.

Matić, D., M. Vlahović, S. Kolarević, V. Perić Mataruga, L. Ilijin, M. Mrdaković, and 606 B. Vuković Gačić. 2016. Genotoxic effects of cadmium and influence on fitness components of Lymantria dispar caterpillars. Environ Pollut 218:1270-1277.

Matranga, V., A. Pinsino, M. Celi, G. D. Bella, and A. Natoli. 2006. Impacts of UV-B 608 radiation on short-term cultures of sea urchin coelomocytes. Mar. Biol. 149

Matranga, V., A. Pinsino, M. Celi, A. Natoli, R. Bonaventura, H. C. Schröder, and W. E. G. Müller. 2005. Monitoring chemical and physical stress using sea urchin

614 Michel, C., and F. Vincent-Hubert. 2012. Detection of 8-oxodG in Dreissena polymorpha gill cells exposed to model contaminants. Mutat Res Genet Toxicol Environ Mutagen 741 (1-2):1-6.

617 Mitchell, D. L., T. Adams-Deutsch, and M. H. Olson. 2009. Dose dependence of DNA repair in rainbow trout (Oncorhynchus mykiss) larvae exposed to UV-B radiation. Photochem Photobiol Sci 8 (1):75-81. 
Mitchelmore, C. L., C. Birmelin, D. R. Livingstone, and J. K. Chipman. 1998. Detection of DNA strand breaks in isolated mussel (Mytilus edulis L.) digestive gland cells using the "comet" assay. Ecotoxicol Environ Saf 41 (1):51-58.

Nacci, D. E., S. Cayula, and E. Jackim. 1996. Detection of DNA damage in individual cells from marine organisms using the single cell gel assay. Aquat Toxicol 35 (3-4):197-210.

Pan, L., and H. Zhang. 2006. Metallothionein, antioxidant enzymes and DNA strand breaks as biomarkers of $\mathrm{Cd}$ exposure in a marine crab, Charybdis japonica. Comp Biochem Physiol C Toxicol Pharmacol 144 (1):67-75.

Pereira, S. M., J. Fernández-Tajes, T. Rábade, F. Flórez-Barrós, B. Laffon, and J. Méndez. 2011. Comparison between two bivalve species as tools for the assessment of pollution levels in an estuarian environment. J Toxicol Env Heal A 74 (15-16):1020-1029.

Pinheiro, J., D. Bates, S. DebRoy, and R Core Team. 2017. nlme: linear and nonlinear mixed effect models. $\mathrm{R}$ package version 3.1-130. https://CRAN.Rproject.org $/$ package $=$ nlme

Pinsino, A., and V. Matranga. 2015. Sea urchin immune cells as sentinels of environmental stress. Dev Comp Immunol 49 (1):198-205.

638 Pinsino, A., M. C. Thorndyke, and V. Matranga. 2007. Coelomocytes and posttraumatic response in the common sea star Asterias rubens. Cell Stress Chaperones 12 (4):331-341.

Pruski, A. M., and D. R. Dixon. 2003. Toxic vents and DNA damage: first evidence 643 from a naturally contaminated deep-sea environment. Aquat Toxicol 64 (1):113. 
644 Rank, J., and K. Jensen. 2003. Comet assay on gill cells and hemocytes from the blue mussel Mytilus edulis. Ecotoxicol Environ Saf 54 (3):323-329.

646 Rank, J., K. Jensen, and P. H. Jespersen. 2005. Monitoring DNA damage in indigenous blue mussels (Mytilus edulis) sampled from coastal sites in Denmark. Mutat Res

Rank, J., K. K. Lehtonen, J. Strand, and M. Laursen. 2007. DNA damage, acetylcholinesterase activity and lysosomal stability in native and transplanted mussels (Mytilus edulis) in areas close to coastal chemical dumping sites in Denmark. Aquat Toxicol 84 (1):50-61.

Rastogi, R. P., Richa, A. Kumar, M. B. Tyagi, and R. P. Sinha. 2010. Molecular 654 mechanisms of ultraviolet radiation-induced DNA damage and repair. J Nucleic Acids 2010:592980.

Reinardy, H. C., A.G. Bodnar. 2015. Profiling DNA damage and repair capacity in sea urchin larvae and coelomocytes exposed to genotoxicants. Mutagenesis 30 (6):829-839.

Rigonato, J., M. S. Mantovani, and B. Q. Jordão. 2005. Comet assay comparison of different Corbicula fluminea (Mollusca) tissues for the detection of genotoxicity. Genet. Mol. Biol. 28:464-468.

Rybakovas, A., Baršiene, J., and T. Lang. 2009. Environmental genotoxicity and cytotoxicity in offshore zones of the Baltic and the North Seas. Mar Environ $\operatorname{Res} 68$ (5):246-256.

665 Singh, N. P., M. T. McCoy, R. R. Tice, and E. L. Schneider. 1988. A simple technique 666 for quantitation of low levels of DNA damage in individual cells. Exp Cell Res 175 (1):184-191. 
Siu, W. H. L., J. Cao, R. W. Jack, R. S. S. Wu, B. J. Richardson, L. Xu, and P. K. S. Lam. 2004. Application of the comet and micronucleus assays to the detection of B[a]P genotoxicity in haemocytes of the green-lipped mussel (Perna viridis). Aquat Toxicol 66 (4):381-392.

Siu, W. H. L., C. L. H. Hung, H. L. Wong, B. J. Richardson, and P. K. S. Lam. 2003. Exposure and time dependent DNA strand breakage in hepatopancreas of greenlipped mussels (Perna viridis) exposed to Aroclor 1254, and mixtures of B[a]P and Aroclor 1254. Mar Pollut Bull 46 (10):1285-1293.

Söderhäll, K., and V. J. Smith. 1983. Separation of the haemocyte populations of Carcinus maenas and other marine decapods, and prophenoloxidase distribution. Dev Comp Immunol 7 (2):229-239.

Tice, R. R., E. Agurell, D. Anderson, B. Burlinson, A. Hartmann, H. Kobayashi, Y. Miyamae, E. Rojas, J. C. Ryu, and Y. F. Sasaki. 2000. Single cell gel/comet assay: Guidelines for in vitro and in vivo genetic toxicology testing. Environ Mol Mutagen 35 (3):206-221.

Venier, P., S. Maron, and S. Canova. 1997. Detection of micronuclei in gill cells and haemocytes of mussels exposed to benzo[a]pyrene. Mutat Res Genet Toxicol Environ Mutagen 390 (1-2):33-44.

Wilson, D. M. I., and V. A. Bohr. 2007. The mechanics of base excision repair, and its relationship to aging and disease. DNA Repair (Amst) 6 (4):544-559.

Wilson, J. T., P. L. Pascoe, J. M. Parry, and D. R. Dixon. 1998. Evaluation of the comet assay as a method for the detection of DNA damage in the cells of a marine invertebrate, Mytilus edulis L. (Mollusca: Pelecypoda). Mutat Res Fund Mol Mech Mut 399 (1):87-95. 
Tables

694 Table 1. Overview of baseline DNA damage from reference sites or laboratory control reported as mean tail intensity (TI) and other end points:

695 olive tail moment (OTM) or damage (\%) using comet assay if not stated differently.

\begin{tabular}{|c|c|c|c|c|c|c|}
\hline Phyla & Species & $\%$ DNA TI & other & Tissue & Method & Reference \\
\hline \multirow[t]{9}{*}{ Mollusca } & Mytilus edulis & $22 \%$ & $3.5 \mathrm{OTM}$ & hemocytes & & present study \\
\hline & & & $2.61 \mathrm{OTM}$ & hemocytes & & Rank and Jensen, 2003 \\
\hline & & $25 \%$ & 5 OTM & hemocytes & & Halldórsson et al., 2004 \\
\hline & & $21 \%$ & & $\begin{array}{l}\text { digestive } \\
\text { gland }\end{array}$ & & Large et al., 2002 \\
\hline & & $14 \%$ & & hemocytes & & AlAmri et al., 2012 \\
\hline & & & $2-4$ OTM & gill cells & & Rank et al., 2005 \\
\hline & & & 3-4 OTM & gill cells & & Rank et al., 2007 \\
\hline & & & $1-2$ OTM & hemocytes & & Dallas et al., 2013 \\
\hline & $\begin{array}{l}\text { Mytilus } \\
\text { galloprovincialis }\end{array}$ & $2.5 \%$ & & hemocytes & & Klobučar et al., 2008 \\
\hline
\end{tabular}




\begin{tabular}{|c|c|c|c|c|c|c|}
\hline & & $8 \%$ & & hemocytes & & Gomes et al., 2013 \\
\hline & & $6-10 \%$ & $5.27 \mathrm{OTM}$ & hemocytes & & Almeida et al., 2011 \\
\hline & $\begin{array}{l}\text { Cerastoderma } \\
\text { edule }\end{array}$ & & $1-2$ OTM & hemocytes & & Dallas et al., 2013 \\
\hline & $\begin{array}{l}\text { Tapes } \\
\text { semidecussatus }\end{array}$ & $24 \%$ & & hemocytes & & Hartl et al., 2006 \\
\hline Echinodermata & Asterias rubens & $34 \%$ & & $\begin{array}{l}\text { coelomocyte } \\
\text { s }\end{array}$ & & present study \\
\hline & & $14 \%$ & & $\begin{array}{l}\text { coelomic } \\
\text { epithelia } \\
\text { cells }\end{array}$ & & Hernroth et al., 2010 \\
\hline & & & $\begin{array}{l}15-25 \% \\
\text { damage }\end{array}$ & pyloric caeca & $\begin{array}{l}\text { alkaline } \\
\text { unwinding } \\
\text { elution }\end{array}$ & Everaarts, 1995 \\
\hline & & & $\begin{array}{l}12-30 \% \\
\text { damage }\end{array}$ & pyloric caeca & $\begin{array}{l}\text { alkaline } \\
\text { unwinding } \\
\text { elution }\end{array}$ & $\begin{array}{l}\text { Everaarts and Sarkar, } \\
1996\end{array}$ \\
\hline Arthropoda & Carcinus maenas & $25 \%$ & & $\begin{array}{l}\text { coelomocyte } \\
S\end{array}$ & & present study \\
\hline
\end{tabular}




\begin{tabular}{|c|c|c|c|c|c|c|}
\hline & $\begin{array}{l}\text { Paleomonetes } \\
\text { pugio }\end{array}$ & $\sim 24 \%$ & & embryo cells & & Hook and Lee, 2004 \\
\hline & $\begin{array}{l}\text { Charybdis } \\
\text { japonica }\end{array}$ & $42 \%$ & & & $\begin{array}{l}\text { alkaline } \\
\text { unwinding } \\
\text { elution }\end{array}$ & Pan and Zhang, 2006 \\
\hline \multirow[t]{8}{*}{ Chordata } & Ciona intestinalis & $17 \%$ & & hemocytes & & present study \\
\hline & $\begin{array}{l}\text { Brotyllus } \\
\text { schlosserii }\end{array}$ & & damaged & hemocytes & visual & Ballarin et al., 2008 \\
\hline & $\begin{array}{l}\text { Brotyllus } \\
\text { schlosserii }\end{array}$ & & damaged & & visual & Liu et al., 2006 \\
\hline & Gadus morhua & $14 \%$ & & lymphocytes & & present study \\
\hline & & & & lymphocytes & & Fredriksen, 2013 \\
\hline & Limanda limanda & $2 \%$ & & erythrocytes & & Hylland et al., 2016 \\
\hline & $\begin{array}{l}\text { Melanogrammus } \\
\text { aeglefinus }\end{array}$ & $7-50 \%$ & & erythrocytes & & Hylland et al., 2016 \\
\hline & $\begin{array}{l}\text { Scophthalmus } \\
\text { maximus }\end{array}$ & $11 \%$ & & erythrocytes & & Hartl et al., 2006 \\
\hline
\end{tabular}


698 Table 2: Studies on species sensitivity exposed to various compounds. The studies results were used to calculate a fold increase of exposure vs.

699 control (exposure/control-1) to show the relative sensitivity of the species by comet assay, sister chromatid exchange (SCE) and chromosomal

700 aberration (CA). All exposure concentrations in the respective studies were converted to micro molar ( $\mu \mathrm{M})$. Letters indicate ${ }^{\mathrm{a}}$ in vivo, ${ }^{\mathrm{b}}$ in vitro 701 and cin situ studies. n.d. = not defined.

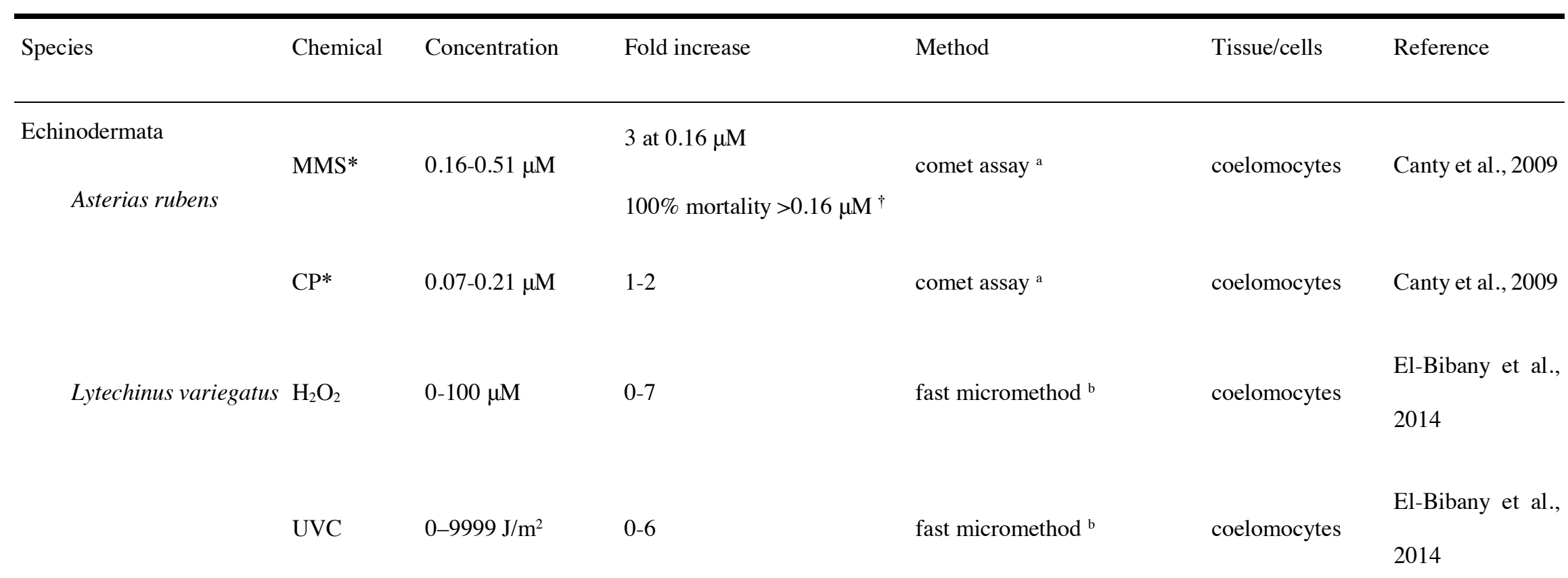


Echinometra lucunter

lucunter

$\mathrm{H}_{2} \mathrm{O}$

$0-100 \mu \mathrm{M}$

$0-8$

Trippneustes

ventricosus

$\mathrm{H}_{2} \mathrm{O}_{2}$

$0-100 \mu \mathrm{M}$

$0-6.5$

UVC 0-9999 J/m²

UVC $\quad 0-9999 \mathrm{~J} / \mathrm{m}^{2} \quad 0-7$

Mollusca

MMS $\quad 0.16-0.51 \mu \mathrm{M} \quad 6-11$

Mytilus edulis

$\mathrm{CP}$

$0.07-0.21 \mu \mathrm{M}$

$3-6$

MMS

$1000 \mu \mathrm{M}$

$9-15$ ast micromethod ${ }^{\mathrm{b}}$

coelomocytes

l-Bibany et al. 2014

El-Bibany et al.,

fast micromethod

coelomocytes

2014

El-Bibany et al.

fast micromethod ${ }^{b}$

coelomocytes

El-Bibany et al., 2014

2014

comet assay $^{\text {a }}$

hemolymph

Canty et al., 2009

comet assay a

hemolymph

Canty et al., 2009

sister chromatid exchange,

chromosomal aberration embryo-larvae

Jha et al., 2002 


\begin{tabular}{|c|c|c|c|c|c|c|}
\hline & TВTO* & $5.4 \times 10^{-4}-$ & $1-6$ & $\begin{array}{l}\text { sister chromatid exchange, } \\
\text { chromosomal aberration a }^{*}\end{array}$ & embryo-larvae & Jha et al., 2002 \\
\hline & $\mathrm{H}_{2} \mathrm{O}_{2}$ & $100 \mu \mathrm{M}$ & 0 & comet assay $^{\mathrm{b}}$ & hemolymph & $\begin{array}{l}\text { Cheung et al., } \\
2006\end{array}$ \\
\hline & $\begin{array}{l}\text { polluted } \\
\text { sites }\end{array}$ & n.d. & $1.5-3.5$ & comet assay $^{c}$ & hemolymph & $\begin{array}{l}\text { Pereira et al., } \\
2011\end{array}$ \\
\hline & $\begin{array}{l}\text { polluted } \\
\text { sites }\end{array}$ & n.d. & $0-1$ & comet assay $^{\mathrm{c}}$ & hemocytes & $\begin{array}{l}\text { Dallas et al., } \\
2013\end{array}$ \\
\hline Cerastoderma edule & $\mathrm{H}_{2} \mathrm{O}_{2}$ & $100 \mu \mathrm{M}$ & 0.4 & comet assay ${ }^{b}$ & hemolymph & $\begin{array}{l}\text { Cheung et al., } \\
2006\end{array}$ \\
\hline & $\begin{array}{l}\text { polluted } \\
\text { sites }\end{array}$ & n.d. & $4-7$ & comet assay $^{\mathrm{c}}$ & hemolymph & $\begin{array}{l}\text { Pereira et al., } \\
2011\end{array}$ \\
\hline & $\begin{array}{l}\text { polluted } \\
\text { sites }\end{array}$ & n.d. & $0-1$ & comet assay $^{c}$ & hemocytes & $\begin{array}{l}\text { Dallas et al., } \\
2013\end{array}$ \\
\hline
\end{tabular}




\begin{tabular}{|c|c|c|c|c|c|c|}
\hline Paphia malabarica & EMS* & $0.14-0.45 \mu \mathrm{M}$ & $1.5-4.5$ & comet assay a & hemolymph & $\begin{array}{l}\text { Kumar et al., } \\
2014\end{array}$ \\
\hline Metrix casta & $\gamma$-radiation & 2-10 Gy & $3-8$ & comet assay a & hemolymph & $\begin{array}{l}\text { Kumar et al., } \\
2014\end{array}$ \\
\hline $\begin{array}{l}\text { elida } \\
\text { Platynereis dumerilii }\end{array}$ & MMS & $1000 \mu \mathrm{M}$ & $9-22$ & $\begin{array}{l}\text { sister chromatid exchange, } \\
\text { chromosomal aberration a }^{~}\end{array}$ & embryo-larvae & Jha et al., 2002 \\
\hline & TBTO & $\begin{array}{l}5.4 \times 10^{-4}- \\
9.4 \times 10^{-3} \mu \mathrm{M}\end{array}$ & $1-5$ & $\begin{array}{l}\text { sister chromatid exchange, } \\
\text { chromosomal aberration a }^{~}\end{array}$ & embryo-larvae & Jha et al., 2002 \\
\hline Arenicola marina & MMS & $0.16-0.47 \mu \mathrm{M}$ & 0.8 & comet assay b & coelomocytes & $\begin{array}{l}\text { Lewis and } \\
\text { Galloway } 2008\end{array}$ \\
\hline Nereis diversicolor & MMS & $0.16-0.47 \mu \mathrm{M}$ & 0.7 & comet assay ${ }^{b}$ & coelomocytes & $\begin{array}{l}\text { Lewis and } \\
\text { Galloway } 2008\end{array}$ \\
\hline
\end{tabular}


$703 *$ MMS $=$ methyl methanesulfonate, $\mathrm{CP}=$ cyclophosphamide, $\mathrm{TBTO}=$ tributyltin oxide, $\mathrm{EMS}=$ ethyl methanesulfonate 
705 Fig. 1. Baseline DNA damage in M. edulis, A. rubens, C. maenas, C. intestinalis and 706 G. morhua. Letters indicate differences between species $(P<0.05$; LME model with 707 Wald $F$-test on the fixed effects with post-hoc Tukey's multiple comparison). Box plots 708 present median, first and third quartile.

710 Fig. 2. Hydrogen peroxide induced DNA strand breaks in cells from M. edulis, A. 711 rubens, C. maenas, $C$. intestinalis and G. morhua. Letters indicate differences between 712 species $(P<0.05$; LME model with Wald $F$-test on the fixed effects with post-hoc 713 Tukey's multiple comparison). Box plots present median, first and third quartile.

715 Fig. 3. DNA strand breaks following $\mathrm{H}_{2} \mathrm{O}_{2}$ exposure and subsequent recovery in cells 716 from M. edulis, A. rubens, C. maenas, C. intestinalis and G. morhua. Letters indicate 717 differences between species $(P<0.05$; LME model with Wald $F$-test on the fixed 718 effects with post-hoc Tukey's multiple comparison). Box plots present median, first 719 and third quartile.

721 Fig. 4. Total DNA strand breaks in cells from M. edulis, A. rubens, C. maenas, $C$. 722 intestinalis and G. morhua, measured using the FPG-amended comet assay. Letters 723 indicate differences between species $(P<0.05$; LME model with Wald $F$-test on the 724 fixed effects with post-hoc Tukey's multiple comparison). Box plots present median, 725 first and third quartile. 


\section{$726 \quad$ Figures}

727 Fig. 1.

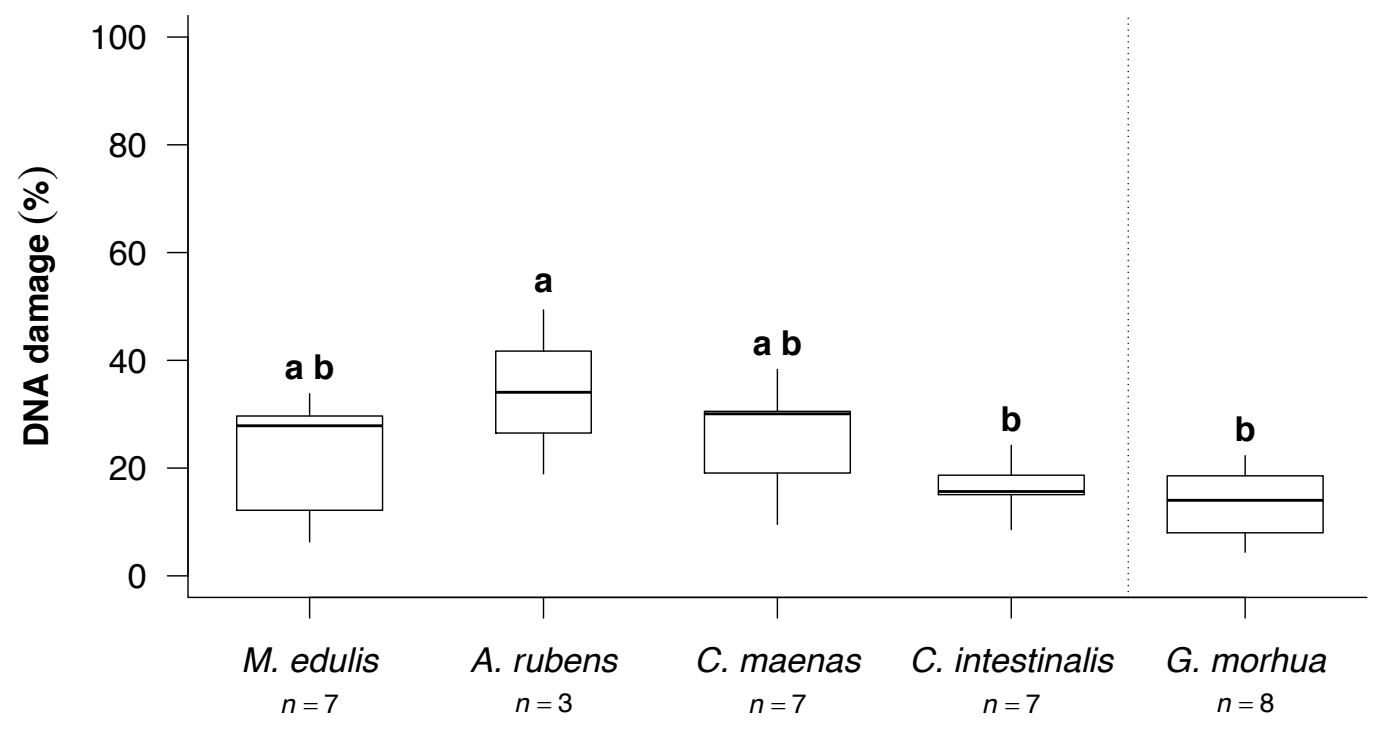

728

$729 \quad$ Fig. 2.

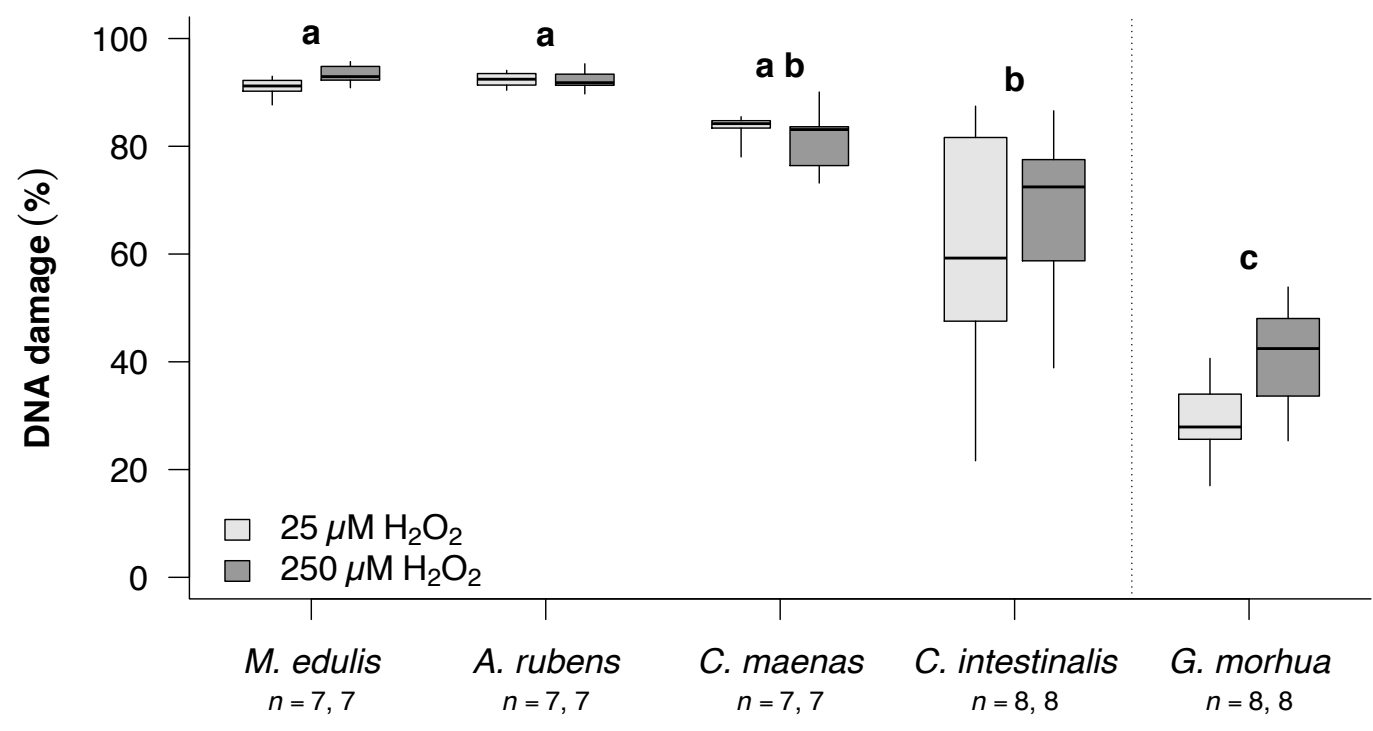


Fig. 3.

733

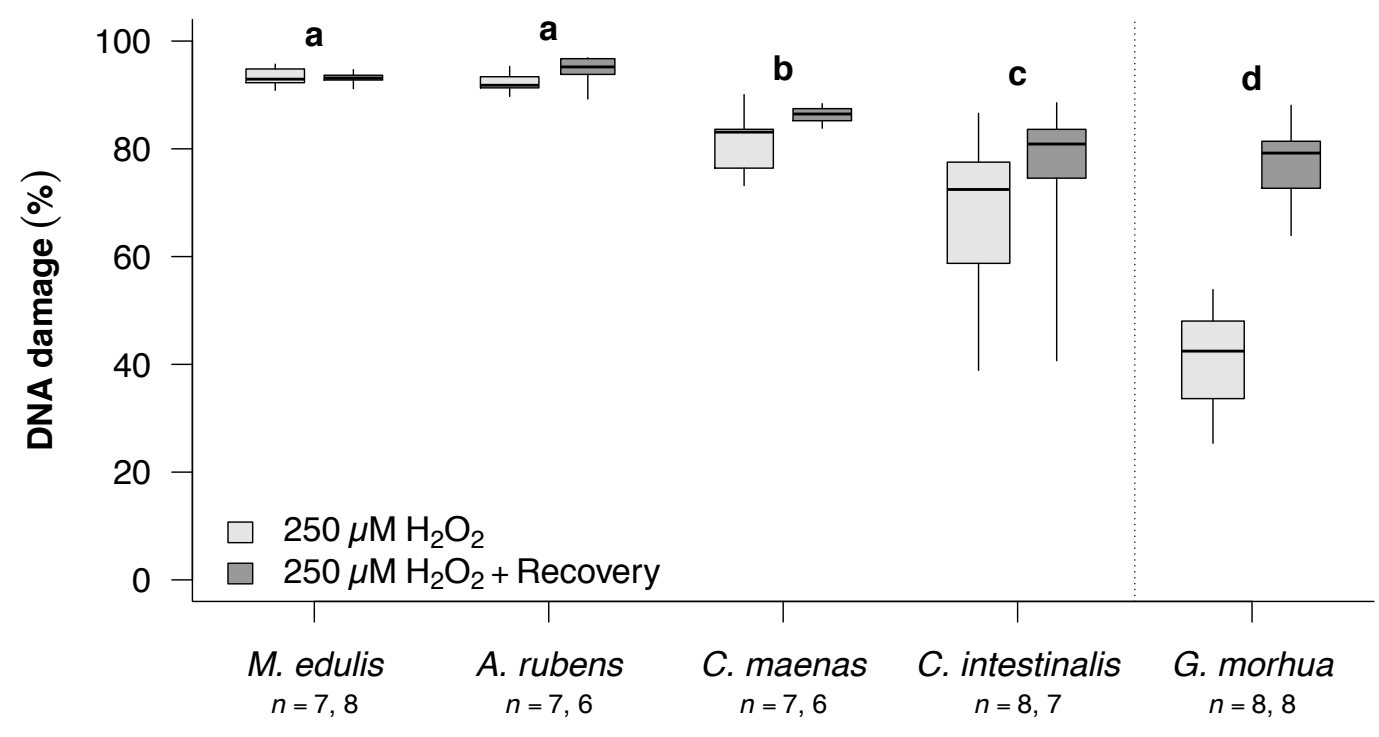

734

$735 \quad$ Fig. 4.

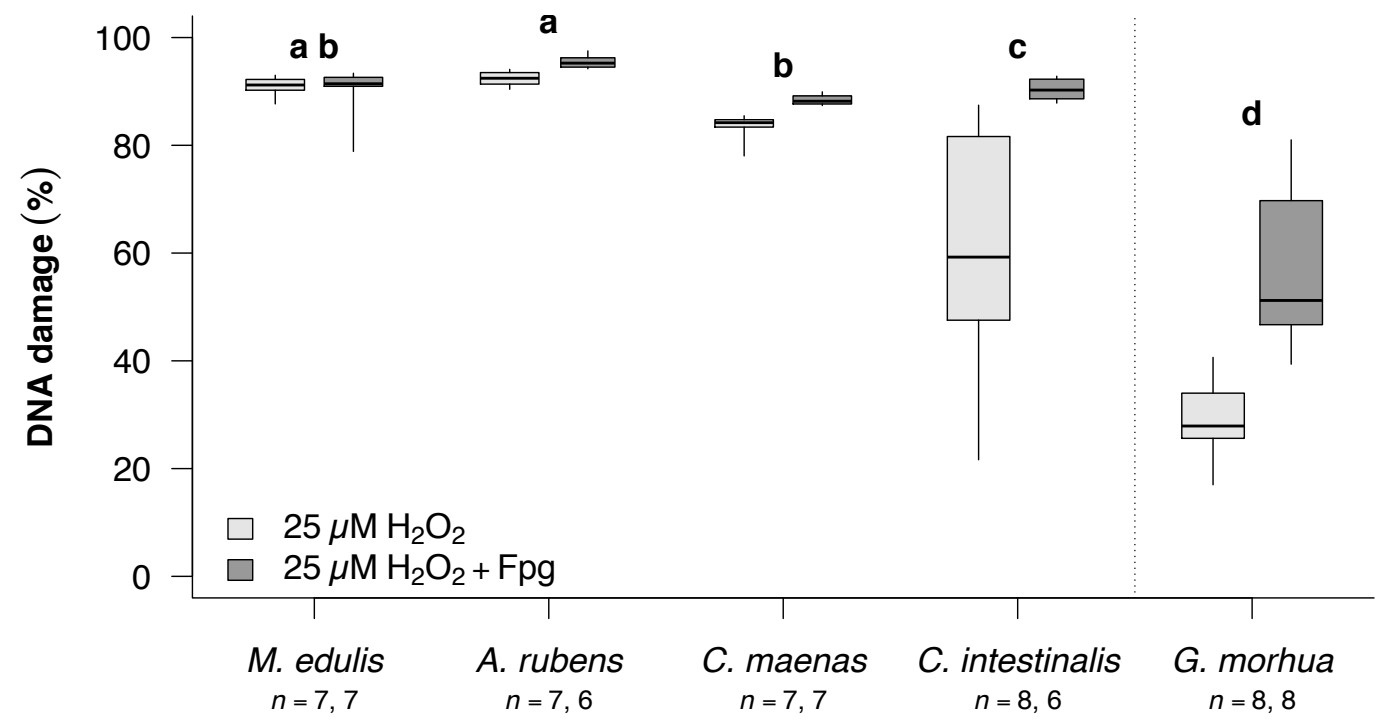

